\title{
Detection on ectoparasites on small ruminants and their impact on the tanning industry in Sulaimani province
}

\author{
B.H.S. Mustafa \\ Department of Animal Science, College of Agricultural Engineering Sciences, University of Sulaimani, Sulaimani, Iraq \\ email: bahzad.mustafa@univsul.edu.iq
}

(Received October 1, 2018; Accepted January 7, 2019)

\begin{abstract}
The study was carried out through the clinical examination on the skins of sheep and goats to identify the quality and processed in the tanneries. Parasitic skin diseases caused by ectoparasites such as mange mites, lice, and ticks are among these threats resulting in a serious economic loss to the tanning industry and the country as a whole. Out of 38066 sheep and 9889 goats examined in Sulaimani slaughterhouse in spring season 2017, shows statistically significant $\mathrm{P}<0.05$ between sheep and goats prevalence; $9.35 \%$ and $7.43 \%$ respectively with one or more ectoparasites. Three different of ectoparasites were infested in both sheep and goats namely; hard tick, lice and mite. Five species of hard tick (Ixodidae) were identified in sheep and goats as follows; Boophilus spp 3.68\% and 14.16\%, Rhipicephalus sanguineous $12.47 \%$ and $28.63 \%$, Rhipicephalus turanicus $7.50 \%$ and $15.96 \%$, Hyalomma a anatolicum $11.90 \%$ and $31.30 \%$, Hyalomma marginatum $9.26 \%$ and $9.95 \%$ ) respectively. Two species of lice were identified in sheep namely, Damalinia ovis $17.74 \%$ and Linognathus stenopsis $13.63 \%$, and D. caprae $10.97 \%$ and L. stenopsis $6.22 \%$ on goats. Highly infested were identified with mite on sheep include Psarcoptic scabiei $13.83 \%$ and Psoroptic ovies $9.98 \%$, while only one species founded in this study in goats namely, Psarcoptic scabiei $22.79 \%$. The overall number of skins refused to tanning industry $164(4.61 \%)$ in sheep and $116(15.78 \%)$ in goat. The difference in the prevalence of skin disease infestation between refused skin in both sheep and goats were statistically significant in ruminants $(\mathrm{P}<0.05)$. This paper deals with major skin defects in occurrence by ectoparasites sheep and goats in Sulaimani province.
\end{abstract}

Keywords: Sheep and Goat skin, Ectoparasites, Sulaimani Slaughterhouse Available online at http://www.vetmedmosul.com

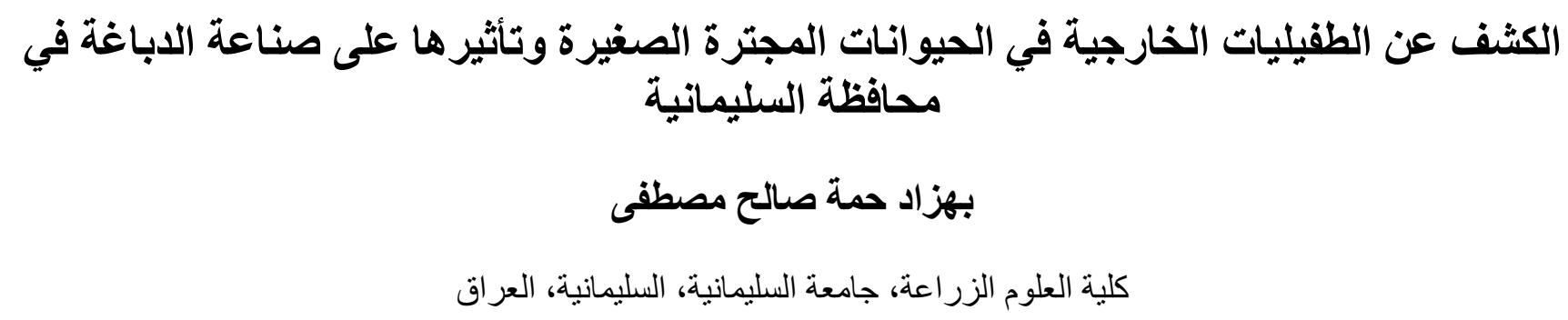

أجريت هذه الدراسة من خلال الفحص السريري على جلود الأغنام والماعز للتعرف على جودتها ودئل ومعاملتها في مصانع الدباغة.

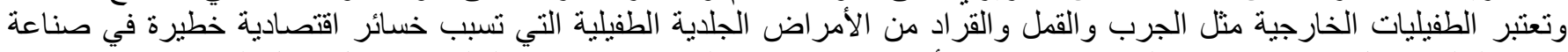

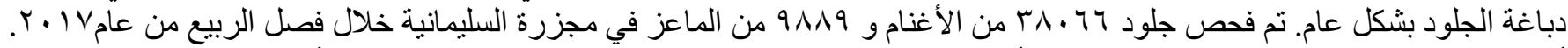

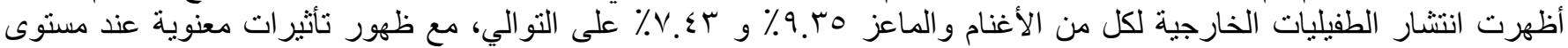

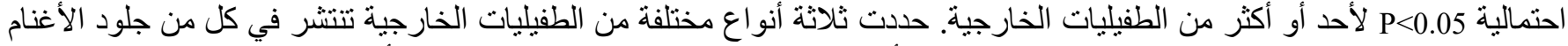

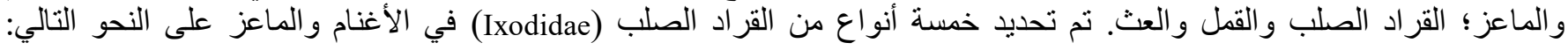

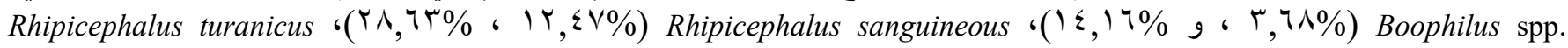

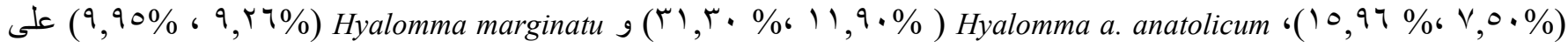




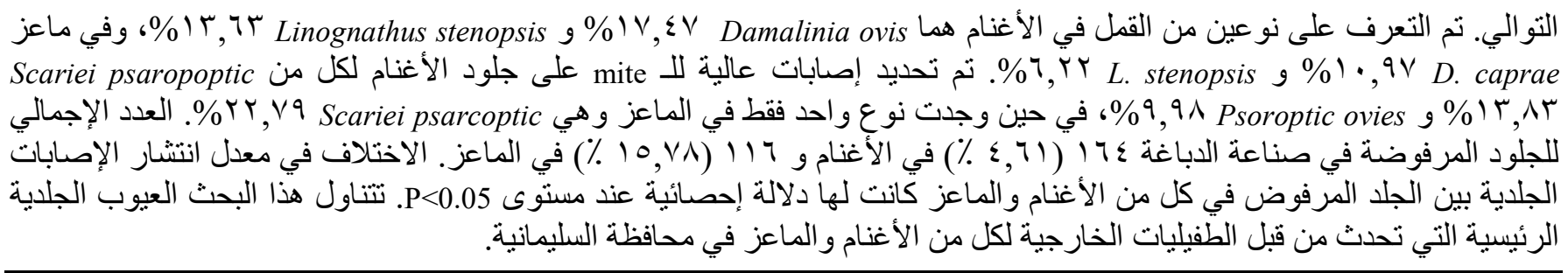

\section{Introduction}

Arthropod pests limit production in the sheep and goat industry in many ways. External parasites feed on body tissue such as blood, skin, and hair. The wound and skin irritant produced by these parasites result in discomfort and irritation to the animal (1). All ectoparasites cause intense irritation to the skin and skin damage (2). The arthropod ectoparasites have a variety of direct and indirect effects on the goat production (3). Tick, mite, lice, and ked are common and important parasites because of their disease transmission, blood feeding habit and skin damage in most of the livestock population (4), which caused by ectoparasites such as mange mites, lice and ticks are among these threats resulting in serious economic loss to the tanning industry. Skin from goat and sheep are important economic products contributing to the largest share of the total and agricultural export commodities (5) followed by live animals (6). The diseases that affect skin quality include: bacterial (Dermatophilosis); viral (pox, warts, foot and mouth disease); parasitic (lice, mange, ticks) (7), the major diseases of small ruminants causing serious economic loss to smallholder farmer, the tanning industry. Skin diseases cause mortality, decreased production and reproduction and downgrading and rejection of skins (8). Mechanical damages of skin most noticeable defects on hiding and skin like brand marks, scratches, scars and bruises are caused by mechanical means. Scratches are very common types of lesions caused mechanically by thorns, barbed wires, and horns; whereas branding is made by owners for animal identification and traditional healing purposing. Climate has also sizable impact on quality of the skin with, respect to the substance of skins and exposure to parasitic damage; highland skins are a bit thinner, less greasy and much stronger in fiber structure than skins from lowlanders (9). Ectoparasites including lice, ticks and mange are reported to cause wide range of health problem such as mechanical tissue damage due to reduction in wool quality meat and milk yield causing serious economic losses to the farmer, the tanning industries and country as whole (10). The present study was aimed to determine the distribution of the common ectoparasites of goat and sheep with risk factors on the quality of skin processing in the tanneries.

\section{Materials and methods}

\section{Study area}

The study on small ruminant ectoparasite was conducted in Sulaimani slaughterhouse during spring season (March, April, and May) 2017.

\section{Clinical Examination}

Isolated and examined healthy and infesting pelts with ectoparasite in sheep and goat during routine inspection examination daily, Examination of each animal was conducted by visual inspection of skin for lesions, if any and by the eventual identification of ectoparasites. When skin lesions were evidenced the detailed history was taken from the owner and subsequently, a skin sample was taken from at least two sites covering the adequate depth and peripheral edges. Lice, ked, and ticks were collected in $70 \%$ ethyl alcohol in vials for preservation until subsequent examination. Skin scraping from suspected cases of mange was collected and preserved in $70 \%$ ethyl alcohol and taken to the laboratory. All samples were properly labeled as described by Wall and Shearer (11).

\section{Specimen collection and identification}

Ectoparasites were examined for the presence of tick, lice and mange mites and collected in a clean container, for detailed laboratory examination and identification by stereomicroscope and identification was performed according to the identification key given by Walker et al. (12) for tick; and Wall and Shearer (13) and Urquhart et al. (14) for lice. Skin scrapings were processed according to the method described by Cole (15). In this method, a few drops of $10 \%$ potassium hydroxide was added to the sample, allowed to stand for 30 minutes, and the sediment was examined under different microscopic magnification for mites, their eggs, and fragments. Mites were identified according to the key described by Wall and Shearer (13).

\section{Skin examination}

Skin in each group and all the skins were individually examined for detect the influence of the genus/species of parasite on sheep and goat skin, isolated the damaged and good type of skin (observed in the skins are pre- and postslaughter) ectoparasite for tanning the processing occurrence by owner's animal. 


\section{Data Management and Analysis}

The data were entered and managed in Microsoft Excel. All the data analysis was done by the Statistical Package for Social Science (SPSS) software version 20. Descriptive statics such as percentages and frequency distribution were used to describe the nature and the characteristics of the data. The association of different risk factors with the prevalence of ectoparasites was computed by Chi-square $\left(x^{2}\right)$ test. In all the analysis, comparisons having a P-value of less than $0.05(\mathrm{P}<0.05)$ were considered as statistically significant.

\section{Results}

Clinically examined for presences of ectoparasites and/ or lesions, the overall prevalence in spring season showed 9.35\% as follows; in March, April and May were 9.32\%, $9.72 \%$ and $9.05 \%$ in sheep respectively, while in goat the overall prevalence of infected pelts with ectoparasite in spring was $7.43 \%$ as follows; in March, April and May were $5.94 \%, 8.32 \%$ and $8.47 \%$ in goats respectively in slaughterhouse- sulaimani province, shows a highly significant prevalence rate of ectoparasites in the spring season, although recorded a slight increase in the prevalence rate of ectoparasites in both sheep and goats recorded a significant difference in prevalence rate between spring months; March, April, and May according to Chisquare $\left(\chi^{2}\right)$ test in sulaimani slaughterhouse of Kurdistan Region (Table 1).

Three genera and four species of ticks were identified in sheep during the spring season. In the study, tick genera of Boophilus spp. (3.68\%), tick genera of Rhipicephalus spp.; includes two species, Rhipicephalus sanguineus (12.47\%) and $R$. turanicus (7.50\%), genera of Hyalomma spp. includes; Hyalomma a. anatolicum (11.90\%) and $H$. marginatum $(9.26 \%)$. Two species of lice identified in sheep were Damalina ovis (17.74\%) and Linognathus stenopsis (13.63\%) in spring season, two species of mange mites were identified; Sarcoptes scabiei (13.83\%) and Psoroptes ovis (9.98\%). The overall of ectoparasites of hard tick 2048 (44.81), Lice 1434 (31.37\%) and mange mite $1088(23.81 \%)$ were collected and identified during the spring in sheep -2017 (Table 2).

Table 1: Prevalence of ectoparasites in sheep and goats selected from Sulaimani slaughter house in spring season -2017

\begin{tabular}{lcccc}
\hline \multirow{2}{*}{ Months } & \multicolumn{2}{c}{ Sheep } & \multicolumn{2}{c}{ Goats } \\
\cline { 2 - 5 } & NO. slaughter & Infested sheep \% & NO. slaughter & Infested goat \% \\
\hline March & 11355 & $1059(9.32 \%)$ & 3887 & $231(5.94)^{*}$ \\
April & 12273 & $1193(9.72 \%)$ & 2979 & $248(8.32)^{*}$ \\
May & 14438 & $1308(9.05 \%)$ & 3023 & $256(8.47)^{*}$ \\
Spring season & 38066 & $3560(9.35 \%)$ & 9889 & $735(7.43)^{* *}$ \\
\hline
\end{tabular}

Chi-square $\left(\chi^{2}\right)$ test, differences significant at the $0.01 * *$ and $0.05 *$ level.

Table 2: Prevalence and identified of genera of ectoparasites examined in sheep in Sulaimani slaughter house

\begin{tabular}{|c|c|c|c|c|}
\hline \multirow{2}{*}{ Type of Ectoparasite } & \multicolumn{3}{|c|}{ No. of ectoparasite collected in infested sheep/ Month \% } & \multirow{2}{*}{$\begin{array}{c}\text { Total of ectoparasite } \\
\text { collected/spring season }(\%)\end{array}$} \\
\hline & March/ \% & April/ \% & May/ \% & \\
\hline \multicolumn{5}{|l|}{ Hard Tick } \\
\hline Boophilus spp. & $42(25.00)$ & $57(33.92)$ & $69(41.07)$ & $168(3.68)$ \\
\hline Rhipicephalus sanguineus & $178(31.22)$ & $191(33.50)$ & $201(35.26)$ & $570(12.47)$ \\
\hline Rhipicephalus turanicus & $104(30.32)$ & $117(34.11)$ & $122(34.56)$ & $343(7.50)$ \\
\hline Hyalomma a. anatolicum & $141(25.91)$ & $176(32.35)$ & $227(41.72)$ & $544(11.90)$ \\
\hline Hyalomma marginatum & $123(29.07)$ & $143(33.80)$ & $157(37.11)$ & $423(9.26)$ \\
\hline Total & $588(28.71)$ & $684(33.39)$ & $776(37.89)$ & $2048(44.81)$ \\
\hline \multicolumn{5}{|l|}{ Lice } \\
\hline Damalinia ovis & $235(28.97)$ & $264(32.55)$ & $312(38.47)$ & $811(17.74)$ \\
\hline Linognathus stenopsis & $177(28.41)$ & $213(34.18)$ & $233(37.49)$ & $623(13.63)$ \\
\hline Total & $412(28.73)$ & $477(33.26)$ & $545(38.00)$ & $1434(31.37)$ \\
\hline \multicolumn{5}{|l|}{ Mite } \\
\hline Sasrcoptes scabiei & 197 (31.17) & $208(32.91)$ & $227(35.91)$ & $632(13.83)$ \\
\hline Psoroptes ovis & $134(29.38)$ & $146(32.01)$ & $176(38.59)$ & $456(9.98)$ \\
\hline Total & $331(30.42)$ & $354(32.53)$ & $403(37.04)$ & $1088(23.81)$ \\
\hline Overall & $1331(29.13)$ & $1515(33.15)$ & $1724(37.72)$ & 4570 \\
\hline
\end{tabular}

Descriptive statistics were used to analyze the prevalence and identified genera species with the number of ectoparasites which collected on sheep infested during the spring season. 
Table 3 showed that Ectoparasites were isolated and classified in goats, similar to sheep when compared between them, that meaning the breeding of both sheep and goats is mixed in this area. Three genera and four species of ticks were identified in goats during the spring season. In the study, tick genera of Boophilus spp. ((14.16\%), tick genera of Rhipicephalus spp.; includes two species, Rhipicephalus sanguineus $(28.63 \%)$ and $R$. turanicus (15.96\%), genera of Hyalomma spp. includes; Hyalomma a. anatolicum $(31.30 \%)$ and $H$. marginatum $(9.95 \%)$. Two species of lice identified in goats were Damalinia caprae (10.97\%) and Linognathus stenopsis (6.22\%) in spring season. Among the spring s only asonone species of mange mites were identified; Sarcoptes scabiei $(22.79 \%)$. The overall of ectoparasites of hard tick 2281 (52.73\%), Lice
1059 (17.19\%) and mange mite 986 (22.79\%) were collected and identified during the spring/2017 (Table 3).

The overall prevalence of sheep was infested with hard tick $961(27.00 \%)$ and $217(29.52 \%)$ in goats. The Prevalence of Mite infested sheep and goats 527(14.80\%) and $120(16.33 \%)$ respectively. Both biting and sucking lice were infested sheep and goats. Out of 514 (14.44\%), sheep and $142(19.32 \%)$ of goats infected with lice Whereas, out of $515(14.47 \%)$ in sheep and $72(9.80 \%)$ in goats show a mixed infested with hard tick and Lice. 428 (12.02\%) and $106(14.42 \%)$ sheep and goats respectively were infested with mixed Ectoparasites; Hard tick and Mite. 615 $(17.28 \%)$ in sheep and78 (10.61\%) in goats infected with mixed infested with Mite and Lice (Table 4).

Table 3: Prevalence and identified of genera of Ectoparasites examined in goat Sulaimani slaughter house

\begin{tabular}{|c|c|c|c|c|}
\hline \multirow{2}{*}{ Type of Ectoparasite } & \multicolumn{3}{|c|}{ No. of ectoparasite collected in infested goats/ Month \% } & \multirow{2}{*}{$\begin{array}{c}\text { Total of ectoparasite } \\
\text { collected/spring season }(\%)\end{array}$} \\
\hline & March (\%) & April (\%) & May (\%) & \\
\hline \multicolumn{5}{|l|}{ Hard Tick } \\
\hline Boophilus spp. & $78(24.10)$ & $102(31.57)$ & $143(44.27)$ & $323(14.16)$ \\
\hline Rhipicephalus sanguineus & $203(31.10)$ & $218(33.38)$ & $232(35.53)$ & $653(28.63)$ \\
\hline Rhipicephalus turanicus & $97(26.64)$ & $126(34.61)$ & $141(38.73)$ & $364(15.96)$ \\
\hline Hyalomma a. anatolicum & $146(20.44)$ & $265(37.11)$ & $303(42.43)$ & $714(31.30)$ \\
\hline Hyalomma marginatum & $48(21.14)$ & $91(40.08)$ & $88(38.76)$ & $227(9.95)$ \\
\hline Total & $572(25.10)$ & $802(35.16)$ & 907 (39.76) & $2281(52.73)$ \\
\hline \multicolumn{5}{|l|}{ Lice } \\
\hline Damalinia caprae & $163(24.11)$ & $246(36.39)$ & $267(39.50)$ & $676(10.97)$ \\
\hline Linognathus stenopsis & $96(25.06)$ & $134(34.99)$ & $153(39.95)$ & $383(6.22)$ \\
\hline Total & $259(24.45)$ & $380(35.88)$ & $420(39.66)$ & $1059(17.19)$ \\
\hline \multicolumn{5}{|l|}{ Mite } \\
\hline Sarcoptes scabiei & $263(26.67)$ & $345(34.99)$ & $378(38.34)$ & $986(22.79)$ \\
\hline Overall & $1094(25.29)$ & $1527(35.30)$ & $1705(39.41)$ & 4326 \\
\hline
\end{tabular}

Descriptive statistics were used to analyze the prevalence and identified genera species with the number of ectoparasites which collected on goats infested during the spring season.

The total number of skin refused164 (4.61) in sheep, whereas in goats were116 (15.78) refused with a significant differences $\mathrm{P}<0.05$ while shows that the most rejected skins infected with hard ticks, lice, mite and in mixed infection; hard tick with lice, hard tick with mite, and mite with lice identified in goat when comparison with sheep. Found a strong association $\mathrm{P}<0.05$ in all infected skins except in mixed skins infected with Hard tick with Lice, Hard tick with Mite shows a highly significant difference at $\mathrm{P}<0.01$ between sheep and goats when test by Chi-square $\left(\chi^{2}\right)$ (Table 5).

\section{Discussion}

This study considers the first details on the distribution, identified and occurrence of some ectoparasites on sheep and goats in sulaimani province. In this study, nine genera and species of ectoparasites belonging to ticks, lice, and mange mites were found infesting goats and sheep in sulaimani slaughterhouse in spring season 2017.

The major identified genera of ticks were Boophilus spp.,Rhepicephalus spp., and Hyalomma spp.,The overall prevalence of ectoparasites $3560(9.35 \%)$ and $735(7.43 \%)$ in sheep and goats respectively. This results agreement with Yacob et al. (16) that indicate the prevalence of ectoparasite $13.80 \%$ in sheep and $7.80 \%$ in goats .The total number collected from Hyalomma spp.967 in the spring season shows slightly more than Rhipicephalas spp. 913 in sheep and in goats which shows the total number of Rhipicephalas spp 1017 is higher and more tolerant than Hyalomma spp. 941. One report was recorded the most of 
them in livestock animals from Iraq except fleas (17). Muhaidi et al. (18) showed the highest numbers of tickinfested with genus Hyalomma spp. in sheep in villages AlFallouja city-Iraq. Their prevalence has been studied by Mustafa (19) observed the high numbers of Hyalomma a. anatolicum have infested the sheep in different zones in Suleiman province and the more frequent species than other species of ticks. Abadi et al. (20) showed that the Hyalomma spp. were higher population frequencies than other species in sheep and goat in Yazd province-Iran. These results contrasting with Mohammad (21) revealed the Rhipicephalus spp. were higher incidence than Hyalomma spp. in sheep and goats in the middle and south of Iraq, the predominant of Hyalomma may be due to their ability to tolerate the dry and harsh environment with little hiding places (22). Razmi et al. (23) identified five species of ticks from sheep and goats Rhipicephalus sanguinus, Hyalomma anatolicum most common and other species encountered Hyalomma anatolicum anatolicum. H.asiaticum on sheep in Iran. However, Nasiri et al. (24) identified two genera were Hyalomma and Haemophysalis and five species including
H. marginatum (44.67\%) Hyalomma anatolicum (43.1\%), $H$. asiaticum $(6.37 \%), H$. dromdareii $(5.55 \%)$ and $H$. sulcata $(0.24 \%)$ from Ilam province-Iran., this variable distribution depending on the zone and grazing system (25). Two species of lice identified in sheep were Damalina ovis and Linognathus stenopsis with a prevalence (17.74\%) and $(13.63 \%)$ respectively, while in goats identified two species of lice in goats were Damalina capriae and Linognathus stenopsis with a prevalence $(10.97 \%)$ and $(6.22 \%)$, this results agreement in sheep but shows contrasting in goats prevalence with Zangana et al. (26) which revealed that the prevalence of lice-infested with two species; Damalinia ovis (75\%) and Linognathus stenopsis (33.3\%) in sheep, while in goats D. caprae $(80.74 \%)$ and L. stenopsis (19.2\%). Yakh chali and Hosseine (27) recorded (67.5\%) on sheep and $(71.4 \%)$ on goats were infested with lice. These were D. ovis $(58.8 \%)$ and D. caprae $(71.4 \%)$ on sheep and goats respectively. Sarkar et al. (28) identified two species of lice; D. caprae (20.8\%) and Linognathus stenopsis (18.4\%) infested on black goats in Bangladesh.

Table 4: Distribution of ectoparasites on infected sheep and goats in spring season

\begin{tabular}{|c|c|c|c|c|c|c|c|c|c|c|c|c|c|c|}
\hline \multirow[b]{2}{*}{$\begin{array}{l}\text { F्ञ̃̃ } \\
\text { 艺 }\end{array}$} & \multirow{2}{*}{ 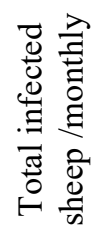 } & \multicolumn{6}{|c|}{ The number of infected sheep with ectoparasite $\%$} & \multirow{2}{*}{ 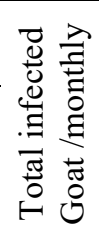 } & \multicolumn{6}{|c|}{$\begin{array}{c}\text { The number of infected Goat with ectoparasite } \\
\%\end{array}$} \\
\hline & & 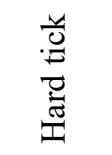 & $\stackrel{\mathscr{N}}{\Sigma}$ &.$\stackrel{\circlearrowright}{\unlhd}$ & 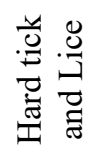 & 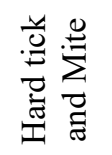 & 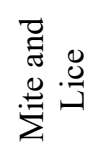 & & 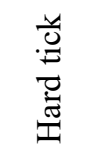 & 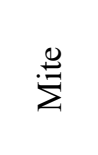 &.$\stackrel{0}{.}$ & 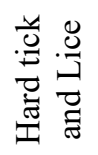 & 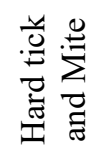 & 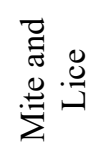 \\
\hline \multirow{2}{*}{ March } & \multirow{2}{*}{1059} & 284 & 148 & 164 & 154 & 128 & 181 & \multirow{2}{*}{231} & 72 & 32 & 49 & 22 & 37 & 19 \\
\hline & & 26.81 & 13.96 & 15.49 & 14.54 & 12.10 & 17.10 & & 31.17 & 13.85 & 21.21 & 9.52 & 16.02 & 8.23 \\
\hline \multirow{2}{*}{ April } & \multirow{2}{*}{1193} & 329 & 176 & 165 & 174 & 141 & 20 & \multirow{2}{*}{248} & 77 & 43 & 46 & 23 & 33 & 26 \\
\hline & & 27.58 & 14.75 & 13.83 & 14.59 & 11.82 & 17.44 & & 31.05 & 17.34 & 18.55 & 9.27 & 13.31 & 10.48 \\
\hline \multirow{2}{*}{ May } & \multirow{2}{*}{1308} & 348 & 203 & 185 & 187 & 159 & 226 & \multirow{2}{*}{256} & 68 & 45 & 47 & 27 & 36 & 33 \\
\hline & & 26.61 & 15.52 & 14.14 & 14.30 & 12.16 & 17.28 & & 26.56 & 17.58 & 18.36 & 10.55 & 14.06 & 12.89 \\
\hline \multirow{2}{*}{ Total } & \multirow{2}{*}{3560} & 961 & 527 & 514 & 515 & 428 & 615 & \multirow{2}{*}{735} & 217 & 120 & 142 & 72 & 106 & 78 \\
\hline & & 27.00 & 14.80 & 14.44 & 14.47 & 12.02 & 17.28 & & 29.52 & 16.33 & 19.32 & 9.80 & 14.42 & 10.61 \\
\hline
\end{tabular}

Descriptive statistics were used to analyze the distribution of ectoparasites such as; the type ectoparasites with the number of sheep and goats infested individually during the spring season.

Table 5: Effects of some ectoparasites on skin quality in sheep and goats

\begin{tabular}{lcccccc}
\hline $\begin{array}{l}\text { Type of ectoparasites } \\
\text { collected on infested } \\
\text { sheep pelts/spring }\end{array}$ & $\begin{array}{c}\text { No. of skin } \\
\text { infected / spring }\end{array}$ & $\begin{array}{c}\text { No. of skin } \\
\text { accepted }\end{array}$ & $\begin{array}{c}\text { No. of skin } \\
\text { refused \% }\end{array}$ & $\begin{array}{c}\text { No. of skin } \\
\text { infected / spring }\end{array}$ & $\begin{array}{c}\text { No. of skin } \\
\text { accepted }\end{array}$ & $\begin{array}{c}\text { No. of skin } \\
\text { refused \% }\end{array}$ \\
\hline Hard Tick & 961 & 914 & $47(4.89)$ & 217 & 188 & $29(13.36)^{*}$ \\
Lice & 527 & 511 & $16(3.04)$ & 120 & 106 & $14(11.67)^{*}$ \\
Mite & 514 & 486 & $28(5.44)$ & 142 & 105 & $37(26.06)^{*}$ \\
Hard tick and Lice & 515 & 492 & $23(4,27)$ & 72 & 66 & $6(8.33)^{* *}$ \\
Hard tick and Mite & 428 & 396 & $32(7.48)$ & 106 & 87 & $19(17.92)^{* *}$ \\
Mite and Lice & 615 & 597 & $18(2.92)$ & 78 & 67 & $11(14.10)^{*}$ \\
\hline Overall & 3560 & 3396 & $164(4.61)$ & 735 & 619 & $116(15.78)^{*}$ \\
\hline
\end{tabular}

Chi-square $\left(\chi^{2}\right)$ test, differences significant at the $0.01^{* *}$ and $0.05^{*}$ level. 
In this study identified two species of mange mites; Sarcoptes scabiei (13.83\%) and Psoroptes ovis (9.98\%) in sheep, and only one species of mange mites were identified in goats; S. scabiei $(22.79 \%)$ and shows a highly prevalent rate and statistically significant at level $\mathrm{P}<0.01$, when associated with sheep infected with $S$. scabiei, the highest prevalence of mite infested in goat due to the difference in management area and decline of dipping process and breeding methods of goats and this methods favorite in sheep in most area in district and subtract in sulaimani province. This results agreement with Hagos et al. (29) revealed that the presence of cockle at pickled stage on sarcoptic mange infested goat pelts group was $100 \%$. Haffeze (30) shows frequencies of mange in sheep and goats were $0.80 \%$ and $1.37 \%$ respectively. Al-Shebani et al. (31) investigated the prevalence of the infestation was highest in sheep more than 2 years. The mange mite $(S$. scabiei) is important cosmopolitan parasites of many domestic mammals causing Sarcoptic mange (32). Zangana et al. (26) revealed that the prevelance of S. scabiei (25.84\%) and Psoroptes ovis (74.15\%), one species of goat was found $(0.1 \%)$ infested with S. scabiei. Yakhchali and Hosseine (27) found (2.6\%) of sheep were infested by $S$. scabiei.

The difference in the prevalence of skin infection with ectoparasites; Hard tick, mite, lice and in mixed infection mite and lice, among sheep and goats host was statistically significant $(\mathrm{P}<0.05)$, while shows a highly significant $(\mathrm{P}<0.01)$ when infection with mixed infection (Hard tick and Lice) and (Hard tick and Mite). The major skin diseases identified on ruminants were tick $47(4.89 \%)$ and 29 (13.36\%), lice 13(3.04) and 14 (11.67), mite mange 28 (5.44) and 37 (26.06), Hard tick and Lice $23(4,27)$ and 6 (8.33), Hard tick and Mite39 (9.11) and19 (17.92), Mite and Lice18 (2.92) and11 (14.10) respectively. with overall of skin refused (4.71\%)in sheep and $116(15.78 \%)$ in goats with a highly significant $(\mathrm{P}<0.01)$ between both small ruminants sheep and goats, Although collected higher number of ectoparasites in infested sheep and Goats but not indicated highly prevalence infestation and skins refused because might be attributed to various important factors including favorable climatic factors, malnutrition especially during long dry season, poor husbandry system, poor awareness of farmers to the effects of ectoparasites, and inadequate animal health services in the study area (28). This agreement with Hagos et al. (29) that indicated a statistically significant association $(\mathrm{P}<0.001)$ between cockle and scratch both on pickled sheep and wet blue goat skins. A similar observation was noted on pickled sheep and wet blue goat skins (33). The effect of these parasites on sheep and goat skins in the spring season showed a slight increase may be because these ectoparasites in the growth and reproduction stage, this results contrasting with Sayyad et al. (34) that investigated that the seasonal ectoparasitic infestation during the study was higher in summer season than winter. Variations in climate and feeding of animals are major factors in determining the quality and impact on quality of the skin with respect to substance of skins and exposure to parasitic damage; highland skins are a bit thinner, less greasy and much stronger in fiber structure than skins (35).The major drawback associated with louse infestation is the basis of reduced hide and skin quality, which impact tanner industry thus it affects country economy. A large number of parasites infect the domesticated animals and are responsible for production loss (36). Skins and the leather industry are still constrained by the poor quality of raw materials, lack of an efficient market structure, a weak extension service, competition from local/rural tanning industries and a lack of price incentive for production of good quality raw material (37). Skin quality is primarily defined by the absence of damage 7 to the grain layer of the skin and finished leather is related to a number of surface and structural defects that hides and skins acquire during the life of the animal, slaughtering, storage and transportation stages (38).

\section{Conclusion}

The present study revealed that extremely high prevalence and widespread occurrence of ectoparasites (especially hard ticks and mixed infested) in small ruminant in the study area, and the major ectoparasites identified were a tick, lice, and mange mite. Ectoparasites are the major causes of skin relegation and rejection in tanneries, revealed that the infested rate in sheep is higher than goats, the present study disclosed that infection by mixed ectoparasites; hard tick and mite in sheep, and lice in goats were found to be strongly associated with defect in skin

\section{References}

1. Ofukwn RA, Akwuobu CA. Aspects of the epidemiology of ectoparasites infestation of sheep and goats in Makurdi North central, Nigeria. Tanzania. Vet J; 2010.27(1):36-42. http://dx.doi.org/10.4314/tvj.v27i1.62766

2. Parola P, Raoult, D. Ticks and tick borne bacterial diseases in humans;an emerging infectious threat. Clin Infect Dis; 2011.15(6):897-928. doi.org/10.1086/319347

3. Elsaid MM, El-Arifi EO, El-Buni AA. The prevalence of ectoparasites on sheep and goats at EL Khoms Region-Libya. J Am Sci; 2013. 9(10):359-363. doi: $10.7537 /$ marsjas091013.48

4. Central Statistics Authority (CSA). Prevalence of Ectoparistes fauna of ruminants in Ethiopia, Addis Ababa; 2004.

5. Ayele S, Assegid W, Jabbar MA, Ahmed MM, Belachew. A review of structure, performance and development initiatives, Socio-economics and Policy Research Working Paper No. 52, Addis Ababa, Ethiopia; 2003. 1-14. ISBN 92-9146-137-7.

6. Central Statistics Authority (CSA). Report on, Size, characteristics and purpose of livestock and use of livestock products (Tigray Region, Central Statistical Agency of Ethiopia; 2008. P.150. 
7. Thrusfield M. Veterinary Epidemiology. $3^{\text {rd }}$ ed. UK: Blackwell Publishing; 2005. P. 433.

8. Tefera, S. Investigation on ectoparasites of small ruminants in selected sites of Amhara Regional state and their impact on the tanning industry. MSc Thesis, Faculty of Veterinary Medicine, Addis Ababa University; 2004. 1-51.

9. Kassa B. 'Pre-slaughter defects of hides/skins and intervention options in East Africa: Harnessing the leather industry to benefit the poor', report at a regional workshop organised jointly by COMESA, LLPI and ILRI, Addis Ababa, Ethiopia, April 18-20, 2005, pp. 71-82

10. Beyecha K, Kumsa B, Beyene D.. Ectoparasites of goats in three agro ecologies in central Oromia, Ethiopia. Comp Clin Path. 2014; 23:2128. doi 10.1007/s00580-012-1563-x

11. Wall R, Shearer D. Veterinary Ectoparasites; Biology, Medicine, and Control, $1^{\text {st }}$ ed. UK: Blackwell Science; 2001. 23-54.

12. Walker AR, Bouattour A, Camicas JL, Estrada- Pena A, Horak IG, Latif A, Pegram RG, Preston PM. Ticks of domestic animals in Africa, A guide to identification of species. UK: Bioscience Reports; 2003. 86-214. ISBN 0-9545173-0-X

13. Wall R, Shearer D. Veterinary Entomology, Arthropod Ectoparasites of Veterinary Importance. $1^{\text {st }}$ ed. UK: Chapman and Hall; 1997. P.439

14. Urquhart GM, Armour J, Duncan JL, Dunn AM, Jennings FM. Veterinary Parasitology. $2^{\text {nd }}$ ed. London: Blackwell Science; 1996. 141-205.

15. Cole HE. Veterinary clinical pathology. Philadelphia: WB Saunders company; 1986. 391-403.

16. Yacob HT, Nesanet B, Dinka A. Part II: Prevalence of major skin diseases in cattle, sheep and goats at Adama Veterinary Clinic, Oromia regional state, Ethiopia. Revue Med Vet; 2008.159:455-461. Website for the Revue de Médecine Vétérinaire,Detail of the article

17. Leiper WJ. Survey of parasites and their control FAO. Roma; 1957. P.14.

18. Muhaidi MJ, Alkubaisy ABH, Ahmed MN, Hamed MA. Study of prevalence of ticks genus Hyalomma spp. and Boophilus spp. of mammalian in Villages Al-Fallouja City. Anbar J. Vet Sci; 2010. 3(1):30- 36. doi: 10.13140/RG.2.2.35088.05124

19. Mustafa BHS. A study on the epidemiology of hard tick (Ixodidae) in sheep and a trial of immunization of rabbits against (Hyalomma anatolicum anatolicum) in Sulaimani governorate-Kurdistan regionIraq [PhD Thesis]. Sulaimani: College of Agriculture, University of Sulaimani; 2011. P. 52

20. Abadi YS, Telmadarraiy Z, Vatandoost H, Chinikar S, Oshaghi MA, Moradi M, Mirabzadeh Ardakan EM, Hekmat S, Nasiri A. Hard ticks on domestic ruminants and their seasonal population dynamics in Yazd province, Iran. Iranian J Arthropod-Borne Dis; 2010. 4(1):66-71. P ISSN: 1735-7179, e ISSN: 2322-2271

21. Mohammad KM. Ixodiod tick fauna infesting sheep and goats in the middle and south of Iraq. Bull Iraq nat Hist Mus; 2016.14(1):43-50. pISSN: 10178678, eISSN: 23119799

22. Kettle DS. Medical and veterinary entomology. $2^{\text {nd }}$ ed, Willingford .CBA international. Oxford University Press. Oxford,UK; 1995. https://trove.nla.gov.au/version/26235990

23. Razmi GR, Naghibi A, Aslani MR, Dastjerd K, Hossieni N. An epidemiological study of Babesia infections in small ruminants in Mashhad Suburb. Khorsan province, Iran. Small Ruminants Res; 2003.50(1):39-44. https://doi.org/ 10.1016/S0921.
24. Nasiri A, Telmadarriay Z, Vatan D, Chinikar SM, Oshaghi MA, Salim A, Sheikh Z. Tick infestation rate of Sheep and their Distribution in Country, llam, Iran. Iranian J Arthropoda-Borne Dis; 2010.4(2):56-60. P ISSN: 1735-7179, e ISSN: 2322-2271

25. Rubaire-Akiiki C, Okello-Onen J, Nasinyama GW, Vaarst M, Kabagambe EK, Mawayi W, Musunge D, Wandukawa W. The prevalence of serum antibodies to tick-borne infection in Mbale District, Uganda: The effect of agro-ecological Zone, grazing management, and age of cattle. J Insect Sci; 2004. 4(8):1-8. https://doi.org/10.1093/jis/4.1.8

26. Zangana IK, Ali BA, Naqid IA. Distribution of ectoparasites infested sheep and goats in Duhok province, north Iraq. Basrah J Vet Res; 2013.12(1):54-64. 10.33762/bvetr.2013.76188

27. Yakhchali M, Hosseine A. Prevalence and ectoparasites founa of sheep and goats flocks in Urima Suburb, Iran. Veteinarski Arhiv; 2006.76(5):431-442. Do Not have doi

28. Sarkar M, Rahman SA, Sarker BK, Begum N, Mondal MMH. Epidemiology and pathology of ectoparasitic infestation in black Bengal goats in Gainbandha and Mymen singh districts of Bangladesh. Bangladesh J Vet Med; 2010.8(1):41-50. doi: https://doi.org/10.3329/bjvm.v8i1.7718

29. Hagos AH, Tolossa YH, Yebegaeshet M. Impact of sheep and goats ectoparasites on the tanning industry in Tigray Region, Ethiopia. Ethiopia Vet J; 2013.17(2):63-76. doi : 10.4314/evj.v17i2.5

30. Haffeze M. Study on Skin Diseases of Small Ruminants in Central Ethiopia [DVM Thesis]. Addis Ababa: Addis Ababa University; 2001. 17-27.

31. Al-Shebani MAA, Dawood KA, Jassem GA. Epidemiological and identification study of mange mites infestation in sheep in AlDiwaniyah province. AL-Qadisiyah J Vet Med Sci. 2012;11(1):20-27. DOI: https://doi.org/10.29079/vol1 1iss1art165

32. Hopla CE, Durden LA, Keirans JE. Ectoparasites and classification. Rev Sci Tech; 1994.13(4):985-1017. PMID: 7711316

33. Yisak E. A Study on Ectoparasites of Fresh Sheep Pelts and Assessment of Pickled Skin Defects Processed at Sebeta Tannery, [DVM thesis]. Addis Ababa: Faculty of Veterinary Medicine, Addis Ababa University; 2000. 18-22.

34. Sayyad B, Mughal SH, Iqbal MN, Ashraf A, Muhammad A. Prevalence of ectoparasites of ruminants in Muzaffarabad District, Azad Jammu and Kashmir. PSM Vet Res; 2016. 01(1):22-25. https://journals.psmpublishers.org/index.php/vetres/article/view/81/52

35. Amsalu D, Bewket S, Kassa T, Tefera T, Gezahgne M, Dagne M, Shihun S. Mange: A disease of growing threat for the production of small ruminants in Amhara National Regional State.Ethiopia; 2000. 80-9.

36. Shaukat N, Khan B, Khan T, Younis MN, Faris N, Javed A, Iqbal $\mathrm{MN}$. A comprehensive review of biogas sector for electric power generation in Pakistan. PSM Biol Res; 2016.1(1):43-48. ISSN: 25179586.

37. Mahmud A. Row hides and skin improvement in Ethiopia status and challenges. Paper presented at technical workshop on good practice for Ethiopian hides and skin industry. March 15-18, 2001, Addis Ababa, Ethiopia.

38. Kidanu C. Hide and skin defects, nature and effect on the industry. In: Proceedings of the Technical Workshop on Good Practices for the Ethiopian Hides and Skins Industry, December 4-7, Addis Ababa, Ethiopia; 2001. 1-7. 